\title{
Reviewing the Interactions between Conflict and Demographic Trends in the Occupied Palestinian Territories: The Case of The Gaza Strip
}

\author{
Ghassan Elkahlout ${ }^{1}$ \\ ${ }^{1}$ Ghassan Elkahlout is a Senior Lecturer at the Center for Conflict and Humanitarian Studies, Doha Institute for \\ Graduate Studies. Prior to joining the Doha Institute, he was the Director of the Humanitarian Forum in London, \\ UK. \\ Correspondence: Ghassan Elkahlout, Center for Conflict and Humanitarian Studies, Doha Institute for Graduate \\ Studies, Al Tarfa Street, Zone 70. Doha Qatar. E-mail: Ghassan.elkahlout@dohainstitute.edu.qa
}

Received: February 11, 2018

doi:10.5539/jsd.v11n3p212
Accepted: April 14, $2018 \quad$ Online Published: May 30, 2018

URL: https://doi.org/10.5539/jsd.v11n3p212

\begin{abstract}
This paper reviews the interactions between conflict and demographic trends in the Occupied Palestinian Territories (OPT), and provides an analysis of The Gaza Strip. Palestinian society has experienced momentous demographic transition over the past century, as well as recurrent waves of displacement and outbreaks of conflict and violence over the last decade. The enclave has witnessed demographic changes, with the emergence and rule of Hamas, repeated wars, and, since 2007, the unlawful blockade of The Gaza Strip. The United Nations (UN) has warned that, living conditions in Gaza are deteriorating faster than forecast, and are predicted to become dire by 2020 . This paper provides a brief review of theories linking conflict and demography, followed by an introduction to the historical and contemporary context of The Gaza Strip. An in-depth analysis of the impact that conflict has on the demographic structure of Palestinian society in The Gaza Strip, focusing on the factors behind high fertility rates, population growth trends, and the drivers of migration. The analysis offered builds upon interviews with Palestinian experts, and Palestinian asylum-seekers in Greece, Poland, U.K. and Sweden, in addition to data published by the Palestinian Statistics Bureau Centre and research articles focusing on The Gaza Strip. The paper concludes that, the Palestinian reconciliation agreement should take priority over the population and the economy.
\end{abstract}

Keywords: conflict, demography, displacement, Gaza, Palestine

\section{Introduction}

Huntington (1993) posits that, the demographic factor is the primary cause of conflict in the post-Cold War era; indeed, demographic changes often play a conspicuous role in political violence. Population growth and resource scarcity have been, and will continue to be, important contributors to political crises and conflict in developing countries (Kahl, 2002). The population structure has featured as an enduring common explanation for contemporary conflict and political instability in the Middle East, particularly in the Occupied Palestinian Territories (OPT), The OPT has experienced continuous stages of demographic changes since the First World War. Britain administered Palestine under a League of Nations mandate approved in 1922 and lasting until 1948. Since then, Palestine has witnessed the Arab loss in the 1948 Arab-Israeli War, the 1967 occupation of the Gaza Strip and the West Bank, the signing in 1993 of the Oslo Accords, the First and Second Intifadas, the 2007 Palestinian conflict between Fatah and Hamas, and the recurrent Israeli assaults on Gaza in 2009, 2012, and 2014

Gaza City is situated in the centre of one of Palestine's 16 governorates. It was substantially larger than the present-day Strip, and contained the coastal cities of Ashkelon and Ashdod, which are now part of Israel (Alexander, 2007). The Strip subsequently shrank to 365 square kilometres, whilst its population swelled to over two million in October 2016. Given the constricted space and population overflow, The Gaza Strip is internationally recognised as being among the planet's most densely populated areas (Murphy, 2017). The UN expects The Gaza Strip to become 'unliveable' by 2020 (UNCTAD, 2015), as a result of this 'high population density and overcrowding'. The division of Palestine and conflict between Fatah and Hamas, the rise of the latter and its rule over The Gaza Strip, Israel's subordination of Gaza with its repeated assaults, the siege of The Gaza Strip by Israel and the blockade of the crossing by Egypt have compounded the issue. Gaza's population has 
been denied access to the Rafah crossing between Gaza and Egypt, and sealed off the only outlet Gaza had to the rest of the world.

This paper provides a brief review of theories linking conflict and demography, followed by an introduction to the historical and contemporary context of The Gaza Strip. The paper then presents an in-depth analysis of the impact that the conflict has on the demographic structure of Palestinian society in The Gaza Strip. An analysis is presented of the factors behind high fertility rates, population growth trends, and the drivers of migration. The analysis offered builds upon interviews with Palestinian experts, Palestinian asylum-seekers in Greece, Poland, U.K. and Sweden, supported by data published by the Palestinian Statistics Bureau Centre and research articles focusing on The Gaza Strip.

\section{Theoretical Linkages between Conflict, Demographic Change and Migration}

Burton's 'Basic Needs Theory' posits that, all human beings, of all cultures, at all times, and in all circumstances, have certain and specific needs that have to be, and will need to be, fulfilled. If left these needs are unaddressed, they will tend to be forcibly 'satisfied' by resorting to violence to obtain them (Burton, 1987). The fulfilment of these needs increases with the level of the pressure on resources as populations change (Choucri, 1984). This assumes that, the relationship between demography and conflict can be seen in a bi-directional way, given that, in certain cases, population change leads to conflict, and in others, the conflict leads to a dramatic change in population characteristics (Choucri, 1984). The social and human implications are considerable in armed conflict, levying the heaviest price on mortality rates. The genocide in Rwanda is an example of the dramatic demographic changes in the male population of combatants (Degomme and Guha-Sapir, 2010).

The impact of conflict on development negatively affects any given population in a conflict zone. This can lead to an increase or decrease in the fertility rate (Woldemicaell, 2008). Advocates of fertility increase claim that, the rate rises because of the crisis; for instance, Abbasi-Shavazi (2001) says the war has encouraged Iranian couples to have more children to replace those being killed on the battlefield. There are others who believe conflict can lead to plunging fertility rates. Lindstrom and Berhanu (1999) argue that, an unplanned limiting of births takes place because of the social and economic difficulties triggered by the conflict. Debarati Guha-Sapir (2010) points out that, conflict also results in a rise in early marriages, harming the general health of young mothers and their children. Women in conflict countries face reproductive health problems, and go through traumatic experiences and psychological stress through lack of access to medical care; furthermore, displacement of people leads to temporary separation of couples; this will ultimately reduce fertility and frequency of intimate contact; thus, poor economic conditions lead to a conscious acclimation in fertility behaviour. According to CEPED (1998), couples tend to avoid having more children in times of trouble. Advocates of this point of view argue that, in conflict zones, family income declines and the support from extended families ceases. This phenomenon is accompanied by an increase in food and commodity prices, and couples become aware of the costs associated with additional children (Rutenberg and Diamond, 1993); on the other hand, there are authors who believe that conflict does not have an impact on fertility rates. Khlat, et al. (1997) for example, state that, the fifteen years' war in Lebanon had little effect on fertility rates.

Goldstone (2002) argues that, unplanned population growth can cause a scarcity of resources, which may trigger conflict. Armed conflict is therefore more likely to occur in countries in which there is a high population growth; moreover, domestic armed conflict is considered more likely in countries with high population density compared to land availability: the greater the imbalance, the stronger the conducive effect it has on conflict. Population growth causes degradation of local resources, resulting in misery and motivating conflict over scant resources (Thayer 2009). Economic productivity may be restricted by environmental scarcities, fuelling poverty, deprivation and migration. Violence may also be caused by grievances in which two factors are present: (i) aggrieved individuals take part in some form of religious, ethnic, or class-based collective, capable of acting against the authorities through violent action; and (ii) the political structure presents openings for violent action to these groups, as no non-violent opportunities exist to have their grievances heard.

De Sherbinen (1996), by contrast, argues that, war is not caused by population growth, but rather, political conflict arises from particular kinds of population changes. Goldstone (2002) similarly elaborates on the fact that, high population growth is not directly related to the probability of stimulating risks, arguing that, it is necessary to take into consideration other factors such as urbanisation that exceeds the employment rate, and migration flows that affect the local balance of indigenous ethnic groups - each increases the prospect of internal conflicts. There is evidence of high population density increasing the risk of armed violence and the risk of state collapse; conflict is caused by the imbalance of population growth in relation to economic growth in certain sectors. 
Conflict is therefore not necessarily a result of population increase, but more likely to be an unequal ratio of land to population, and economic inequity.

UNRWA (2007) explains that, the relationship between population and warfare involves population dynamics and population composition, which, according to Thayer (2009), is comprised of population age, size, gender, and infant mortality. Population dynamics relating to how, over time, the composition of a population changes in relative proportions or absolute size, are also critical, in particular, population growth and migration. It is essential to consider that a universal population change takes place in broader political, cultural and economic contexts (Thayer 2009). A young age (youth) structure can have a positive or negative impact. Seen optimistically, youth 'bulges' provide a greater labour supply which supports economic growth. This, in turn, reduces the propensity for conflict - effectively serving as a 'peace dividend'. The youth bulge hypothesis highlights the increased risk of the occurrence of low intensity conflict in countries and areas with substantial youth cohorts. There have been many recent conflicts in which large youth bulges, combined with youth exclusion, that have fuelled renewed conflict and jeopardised fragile peace settlements (Goldstone et al., 2012). This indicates that, youth bulges, together with poor governance and lack of economic growth, make an explosive combination when brought together with greater inequalities. A considerable security challenge is consequently faced by many developing countries in parts of the Arab world, Asia, and Sub-Saharan Africa. States are able to mitigate and reduce the risk posed by demographic developments however, by providing young people with access to education, employment, and opportunities for political participation. Lin (2012) writes, 'A large cohort of young people cannot find employment and earn satisfactory income; the youth bulge will become a demographic bomb, because a large mass of frustrated youth is likely to become a potential source of social and political instability'.

High fertility rates and unplanned population growth create incentives for people to move to a location in which they can fulfil their needs, and so fuel migration within and across borders (Daly 2004). Internal migration, triggered by population growth, can add pressures on social and political institutions, as population balances among ethnic groups change, urban infrastructures are overwhelmed, limited water and food supplies, and agricultural and industrial production are suppressed. The hostility between Syrian refugees and Lebanese host communities is an example of the tension this creates when it poses economic or social burdens on host communities. According to World Vision (2015), demographic shifts resulting from massive displacement create competition over resources such as housing and the economy, as well as a lack of access to quality education and water, and shortages of electricity. The diminishing quality of public services, rising inflation, differences in social norms, and the role of international aid, are also seen as core drivers of tension. Elites may also use the nativist argument to shore up their political base by stirring up inter-group conflict (Swain 1996: 969-970; Saunders 1991: 2). Migration may strengthen or weaken national power, alter a country's ethnic or communal composition, or trigger resource scarcities - thus indirectly causing conflict.

\section{Context of the Gaza Strip}

The Palestinian-Israeli conflict has lasted for more than 100 consecutive years, and is one of the most protracted in the modern world. Its roots stretch back to the late 19th century, when one of the founding forefathers of Zionism, Theodor Herzl, called for a Jewish state to be created on the land of historic Palestine. Herzl established the World Zionist Organization in 1897, which encouraged European Jews to migrate to Palestine, in an attempt to form a Jewish state. The tiny enclave fell into the hands of British forces during the First World War, falling under the British Mandate over Palestine. Following the 1948 Arab-Israeli war, Egypt took control of the territory of the Gaza Strip, which was in 1967 then occupied by Israel. Palestinian self-rule was established under the Gaza-Jericho Agreement forged in 1994, after the Oslo agreement was signed by the Palestine Liberation Organization (PLO) and Israel the year prior. In 2006, conflict arose once more as Fatah refused to transfer power in Gaza to the Islamic Resistance Movement (Hamas) following a contested election. Hamas' victory stunned Israeli officials who continuously stressed their refusal to deal with a Palestinian authority of which Hamas were a part (Washington Post, 2006).

The Israeli military relationship with Gaza began to take on a more brutal form since 2006: escalation of the military strategy adopted saw the siege on Gaza intensify. Three wars between Israel and Hamas followed the three-week armed assault by Israel with Operation Cast Lead in 2008/09, Operation Pillar of Defence in 2012, and most recently, Operation Protective Edge in 2014. These wars have had a devastating economic and humanitarian impact on the population of Gaza. According to UNDP (2016), the wars have caused 'vast damage to public and private infrastructure including schools, hospitals, water and power plants, industrial infrastructure and agricultural land. The internal Palestinian political divide and the prolonged closure of the Rafah Border Crossing continue to hamper economic and social development'. 
Gaza has been under siege: first by Israel and then later by Israel and Egypt. The siege has had devastating consequences for Gaza's people. OCHA (2017) notes the increasing hardship suffered by its population, highlighting the increasing failure of Gazan institutions to deliver basic services, to respond to emergencies, and to enforce the rule of law - describing Gaza as 'facing a downward spiral of de-development, while the people in Gaza are caught in a cycle of humanitarian need and perpetual aid dependency'. Amnesty International (2017) argues, 'The siege has unlawfully deprived Palestinians in Gaza of their most basic rights and necessities. Under the burden of the illegal blockade and three armed conflicts, the economy has sharply declined and humanitarian conditions have severely deteriorated.' It is predicted that Gaza's water source will become depleted by 2020 (World Bank 2016); furthermore, The Gaza Strip suffers from a widespread shortage of electricity: it requires some 450 megawatts, but the supply is as low as 90 megawatts (OCHA 2017).

The Gaza Strip has suffered a protracted economic crisis, as the population's access to jobs in Israel has decreased whilst economic growth and job creation in the coastal enclave has declined by the destruction of vital public infrastructure as well as private business assets in repeated military assaults by Israel. According to Schembri (2010), 'more than 76,000 jobs will be required each year in Gaza'. The unemployment rate in Gaza Strip remained high in 2016, at 42 per cent; particularly alarming is the high youth unemployment rate, standing at 58 per cent. Poverty rates remain high, with 80 per cent of Gaza's residents receiving some form of aid (World Bank, 2017); even before the crisis, most of the Gazan population could not afford to meet their food needs some 67 per cent now live below the poverty line, surviving on less than two dollars a day, whilst poverty and extreme poverty have risen to more than 65 per cent. According to UNRWA (2015), nearly ' 80 percent of the population receives social assistance', whilst 60 per cent receive relief assistance from UNRWA and international relief organisations: an increase of more than one million people.

Hardship has led Gazans to suffer compounded psychosocial vulnerabilities where young people experience conditions such as depression, attention deficit disorder and conduct disorders, PTSD and anxiety, nightmares and enuresis (bed-wetting) (Courbage et al., 2016). The violence and brutality of conflict are linked to 'a range of psychological and behavioural problems, including depression and anxiety, suicidal behaviour, alcohol abuse and post-traumatic stress disorder' (Courbage et al., 2016).). Suicide has been evident in The Gaza Strip in the last few years (Groisman, 2016), caused by the growing suffering fuelled by the shortage of job opportunities, the siege and the electricity shortage. Having displayed the dire situation in Gaza Strip resulting from three wars and ten years of blockade, the following will closely examine population trends in The Gaza Strip.

\section{Demographic Trends in the Gaza Strip}

Gaza continues to face the consequences of the conflict, blockade, and division, while it also tries to cope with the scant resources available to its growing population. Gaza is amongst the most densely populated areas on the planet - 5,324 persons $/ \mathrm{km}^{2}$, and has the fifth highest population density of any territory (The Guardian, 2017).The total population of 1.94 million consists of 988 thousand males and 956 thousand females (PCBS, 2017). This does not include Gazans born outside The Strip, since they cannot be registered in Gaza, as they are unable to make the journey back due to the on-going siege. Refugees in Gaza represent a substantial part of the Palestinian population of which there are 1.3 million - more than half of the total population (UNRWA, 2017).

Focusing on key demographic groups in Palestinian society, provides a helpful means by which to present the shifting age distribution. Key indicators of demographic change are the population of working-age, elderly people, and those of school age - as well as the growth rate of children. According to UNRWA, these levels, and the changes in them, are critical for public and private sector social and economic planning. Despite the occupation, armed conflict and repeated migration waves since the middle of the 20th century until 2017, The Gaza Strip's population has multiplied by a factor of nine - from 80,000 in 1947 to 1.94 million in 2017, with annual growth averaging 3.5 per cent (UNCTAD, 1994 and UNESCO, 2017).

The Gaza Strip's population pyramid is primarily composed of young people under the age of 14, who constitute the highest percentage of all categories. This group constitutes 42.6 per cent in The Gaza Strip. The elderly population aged 65 years and over constituted 2.4 per cent in The Gaza Strip by mid-2017 (PCBS 2017). This presents critical implications for policy-makers and planners in the service sectors. The enclave's young population is growing rapidly, yet, over the years, opportunities for young people have continued to decline. Courbage et al. (2016) present an optimistic picture emerging from the age-pyramid, arguing it will change due to a decrease in the proportion of youngsters aged below 15 years, whose number is expected to continue to decrease until 2030. 


\section{Drivers of Fertility Rates in Gaza}

The Gaza Strip has experienced a decrease in birth rates, but its population continues to grow as a result of a fertility rate which remains amongst the highest globally, and double that of more developed areas in the region. A survey in 2014 showed that, the total fertility rate in the coastal enclave had fallen to 4.5 births per family during 2011-2013, compared to 6.9 births per family in 1997. It is anticipated that the trend in declining birth rates will continue, arriving at 2.41 per family in 2050 , but the rate will not drop below replacement level. A high fertility rate, combined with population momentum, will see the population of The Gaza Strip more than double to 4.8 million persons. (Courpage et al., 2016).

The following is a discussion of the multiple factors affecting the fertility rates in Gaza

Fertility is widely perceived to be a tool of resistance in a context of decades of occupation, conflict and siege. Alshair holds that, the general trend in Gaza shows that families wish to have more children, particularly when hostilities with the Israelis are high, as there is a belief that children replace the 'martyrs' (those who have elected to die for a cause - jihad) - and provide future fighters. (Note 1) Coghlan (2014) explains, 'in a situation where disempowerment, underemployment and marginalization have left few opportunities for expression of identity, reproduction is one of the few liberties which remains, and also contributes to the larger goal of increasing the Palestinian people'. Palestinians consider high birth rates to be a form of resistance against the Israeli occupation. They reject birth control, as the historical Palestinian leader, Yasser Arafat, alluded to in his assertion that 'the womb of the Palestinian woman is my best weapon' (Arafat, 2017). A deeply held cultural value in Gaza views large families as a form of Palestinian patriotism and as a practical means of thwarting Israeli occupation policies (Khayat, 2009). Palestinians widely share the belief that a large family plays a crucial role in strengthening the family, as a sign of patriotism (Arafat, 2017).

Large family sizes are often the most economically rational strategy for livelihoods in Gaza where decades of Israeli strategies of de-development have eroded conventional social safety nets or the capacity to enact effective social policies (Roy, 2016). The social convention holds that, the more children, the more support the parents will receive later in life. This social norm is perpetuated through widespread practices in which Palestinian children are raised with a keen sense of responsibility to family members; older parents and grandparents rely on the financial support and care of their children and grandchildren. There are three types of familial structures that characterise Palestinian society in The Gaza Strip: tribes, clans, and prominent families (Robinson, 2008).

Alshair argues, large family sizes are also explained by the cultural value attached to having more male family members. The strength of this social convention on shaping family planning is clearly illustrated by the case of a father of ten who explains that, he had a small but happy family of one son and one daughter. Family pressure convinced him that 'another brother was needed for the two children'; in less than ten years, he had eight more children - all daughters. (Note 2)

Alshair explains that, having a large family is a religious duty, which consequently also contributes towards the high fertility rates in Gaza. Alshair elaborates on the religious tradition, the Sunna of the Prophet Muhammad who advises Muslims to 'Marry, because I will vie the nations in number by you (Al-Hindi, 1974);

however, newly married couples typically prefer to practice birth control due to the difficult economic, social and humanitarian situation. They also believe having smaller families secures a better education for their children. This is driven by a heightened awareness of the current situation, and the barriers to securing a decent job in the future, which will allow them to live a dignified life (Abou Jalala, 2013).

(vi) Weaknesses in public health policies and their implementation have hindered birth control. The relatively high rate of unintended pregnancies in the Palestinian Territory suggests that 'women are not taking advantage of available services' (Hammoudeh, 2014). Harab (2018) explains, however, birth control is not readily available, in large part due to the dependence of the health system on international aid. This renders the Gazan population even more vulnerable to budget cuts planned by international organisations, and to deterioration in living conditions. (Note 3)

The population growth resulting from a high fertility rate has already had critical consequences on social and political development within The Gaza Strip. These effects are being exacerbated as the rapidly growing youth segment swells the working-age population - worsening the unemployment problem; under the current political circumstances and protracted economic crisis, the growth of Gaza's youth population has contributed to unprecedented unemployment and poverty levels. 


\section{Migration}

The prevailing dire conditions and the grave economic consequences that have arisen from the Israeli occupation, have functioned as push factors for Palestinians, especially the young, as they search for solutions to the multiple social and economic problems that they face (Su, 2015). The Gaza Strip has witnessed waves of migration in and out throughout the last seventy years, since it provides an individual solution for those seeking to enhance their economic situation. Palestinian families adapt to migration as a coping mechanism to survive the conditions imposed by the occupation, wars and blockade (Courbage et al. 2016).

A large section of the population emigrated to surrounding Arab countries and beyond, in response to the political and security measures implemented by the Israeli occupation forces since 1967, in addition to the significant role played by the economic factors; many migrants have left Gaza in search of education opportunities elsewhere, in particular, the surrounding Arab countries who share a common language, culture, and educational system. Economic stagnation and high unemployment rates also push many other Gazans to emigrate further afield.

The Gaza Strip witnessed a pattern of reverse migration at the beginning of the 1990s. The most intense period of immigration occurred after 1993 with the signing of the Oslo Accords, which provided for the return of a large proportion of the Gazan and Palestinian population. Tens of thousands of returnees made their homes in the West Bank and Gaza, in the first half of the 1990s; by the end of the decade, following the outbreak of the Second Intifada, emigration from these areas resumed its earlier trajectory (Hilal, 2007); consequently, approximately 500,000 people returned to The Gaza Strip and the West Bank during the period 1997 to 2010. This resulted in a sudden and rapid population growth in the OPT, with no prior planning and preparation to accommodate the large influx of returnees. The multiple waves of the Palestinian inflow sparked an unprecedented shortage in essential resources, services, and facilities - but more importantly, it redefined the demographic landscape of the OPT with the blockade on Gaza. Those directly affected by the closure were primarily young men who had been employed in Israel's construction, service and agricultural sectors. Entrepreneurs and self-employed contractors who conducted business inside Israel were therefore 'prohibited from pursuing those options after closure' (Syre and Olmsted, 2012).

War and misery in Gaza have more recently pushed Palestinians to pursue illegal immigration through the shores of southern Europe. Gaza has been subjected to a strict Israeli blockade since 2007, which restricts the movement of goods and people in and out of the territory. The Egyptian-controlled Rafah Crossing was closed in mid-2013 following a military coup, resulting in the Israeli-operated Erez, or Beit Hanoun crossing becoming the only gateway to the world for Gazans. Interviews with Gazan immigrants in Europe offer insights into the hazardous journey that they undertook. One explained that, he arrived in Alexandria in Egypt, and, from there, was taken by a 'people-smuggler' to Greece. (Note 4) According to him, 'it was a hellish journey to reach Italy and later Sweden'; despite the difficulties, most of the Gazan youth is willing to migrate to Europe, even those who have jobs and earn decent incomes, want to leave Gaza. Abed grasped the opportunity, when the borders were opened. He left Gaza for Egypt with no destination in mind, and used a visa he obtained to fly to China. He failed to reach Sweden from China on two occasions, but was successful the third time. 'Sweden is my homeland', he euphorically declared. Abed's explanation is worth quoting:

I had a job in Gaza where I was making a decent income as I was working in the tunnel business. However, I was not able to survive the wars, the lack of security and the lack of future opportunities for my children. This motivated me to travel to Australia. However, I was not successful in gaining refugee status. I had to go back to Gaza to work for another five years to save for my second journey. I have had to pay over $\$ 25,000$ (USD) to come to Sweden. (Note 5)

The author interviewed several cases of Gazan families stranded in Athens in 2011, and Poland in 2012. A mother of three explained that, she has sold her jewellery to fund her journey. She travelled legally first to Egypt and from there to Turkey. A people smuggler took her and her children to Greece from Turkey, during which she faced a perilous sea voyage. The Gazan woman, in her late twenties, describes the decision she made so that she could reach Europe:

I have taken this risk so I can have a future for my kids. I expected that I might die; however, this did not stop me from taking the risk. If I stayed in Gaza, I would die every day. Once I attain refugee status, I will be able to invite my husband to join me. (Note 6)

Another motivation for migration is to receive medical treatment that is unavailable in Gaza. The siege of Gaza has had a disastrous impact on Gaza's battered infrastructure and has set in motion a public health crisis. Thousands of lives, including those of hospital patients with chronic conditions or in need of intensive care, 
including babies on life support, are endangered by the recurrent electricity cut-outs (Amnesty International, 2017). One Gazan refugee, an academic named Dr Saed, received an invitation to attend a workshop at a British university; (Note 7) as he was in a senior academic position at a Gazan university, he could obtain the visa - six months after his arrival, he was granted refugee status in the U.K. He explains:

I had a job in Gaza; however, my three children were suffering from chronic haemophilia. The Ministry of Health in Gaza was not able to provide the required treatment for the three children. It [would] cost $\$ 10,000$ monthly for the expensive medicine. In the U.K., the National Health Service (NHS) looks after the kids.

Mohammed, a Gazan in his late twenties, describes how he sought asylum in Belgium, in order to study for a $\mathrm{Ph} . \mathrm{D}$. without the need to pay education fees. He plans to stay in Belgium until he receives his doctorate; and. intends to return to Gaza, once he completes his post-graduate education (Note 8).

Others decided to leave because they were unable to live under the strict rules of Hamas - they are politically opposed to the ruling Islamic movement. I met a former Palestinian National Authority (PNA) security officer in Alexandria, Egypt, who decided to leave Gaza after 2007. He and a group of PNA officers left after three years of living in Gaza, because they could no longer tolerate the Islamist movement restrictions (Note 9).

Young people aged 15-29 years old, notes Al Waheidi, are the age group most likely to wish to emigrate. Males express a stronger desire to move abroad than do females (PCBS, 2015). This is unsurprising, given socio-cultural traditions in which females typically access only minimum levels of education or financial security, and males assume responsibility for securing living conditions. Interestingly, Courbage et al (2016) show no variance in viewpoints of external migration between Gazans who were educated and those who were not. Indeed, some 13.3 percent of Palestinians aged 15-59 years-old desire to emigrate, claim Courbage et al (2016) - and about 30 percent of these wish to settle elsewhere on a permanent basis. Economic factors behind this include scant job opportunities, inadequate income and poor living conditions:

What I noticed when I was measuring the percentage of those who want to emigrate was that it is constantly on the rise, and this is because of economic reasons and the desire of young men to find jobs, especially as unemployment here is 45 per cent. (Al-Waheidi, 2016)

The research conducted by Al-Waheidi shows education is the motivation that 18.7 per cent of respondents attributed their wish to leave, whilst some 6.6 per cent said the ongoing insecurity in the region was the reason they wanted to emigrate. The desire to emigrate is higher in governorates in the north and middle of Gaza, areas characterised by poor economic conditions. Those living in the southern governorates, for example, face higher levels of poverty and unemployment than elsewhere in the enclave.

According to Courbage et al. (2016), all aspects of life in Palestinian society have been impacted by the social and economic implications arising from migration. It is witnessed, for example, in 'shaping the Palestinian middle class in the diaspora in general, as well as in the replication of conservative culture (Note 10). Services and infrastructure are seen to be upgraded, and living standards improved. Jobs are created locally and economic activities diversified, whilst expertise building, education, and career development see crucial human capital developed abroad. Productive resources have been critically drained in part due to migration, creating significant and challenging consequences for social capital in Gaza (Courbage et al., 2016).

\section{Conclusion}

The situation in The Gaza Strip has increasingly deteriorated since 2006. Demographic pressures in terms of population density, age structure, and growth rate are very high, compared to neighbouring countries and regions. The persistent high fertility rate is fuelled by a number of political, economic, socio-cultural, religious and historical factors. Population pressure, combined with the lack of employment opportunities, and pervasive poverty arising from the Israeli blockade, recurring wars and military assaults, limited resources and territorial isolation, together exert an immense strain on the welfare, public services, social and political institutions, and the natural resources in Gaza, which are already inadequate for the needs of the population. This ordeal constrains the capacity of the Palestinian authorities to effectively provide basic services. The result is a rising trend in those who want to leave Gaza due to economic reasons, in particular, the desire of young men to find jobs and education opportunities. This paper argues that, this situation is likely to continue and worsen over the coming years, unless the underlying demographic drivers are addressed. Gaza's economy, infrastructure, and vital services recovery from wars and the blockade, depends on access to jobs, fewer restrictions, and a political solution is reached. It must be concluded that, without quick population policies to respond to its rapid growth and lack of opportunities, Gaza faces a ticking time bomb. This looming demographic challenge must be 
urgently considered by the PNA, with an opportune moment now presenting itself with the Hamas-Fatah reconciliation agreement signed in October 2017. Palestinians should prioritise reviving the Palestinian economy with foreign support, thus redressing the multiple structural obstacles facing The Gaza Strip, such as the high unemployment rates and the need to create widespread job opportunities. This paper has provided an analysis of the long-term changes in Gaza's population structure in relation to conflict and development that Palestinian policy-makers should bear in mind, whilst attempting to tackle the current existential crisis that The Strip faces.

\section{References}

Abbasi-Shavazi, M. J. (2001). Recent Changes and the Future of Fertility in Iran. Retrieved December 22, 2017, from https://goo.gl/2SUYC7

Abou Jalal, R. (2013). New Palestinian Generation Opts for Fewer Children. AL Monitor, 15 October 2013. Retrieved January 22, 2018, from http://bit.ly/2iZh4cu

Abu-Al-Namel, H. (2009). Demographic Growth and Demographic Balance Between Arabs and Jews in Israel and Historical Palestine. Journal of Arab Future, 370, 73-87. (Arabic).

Al Waheidi, M. (2016). Gaza's youths leave homes in search of a better life. Channel New Asia, 16 March 2016. Retrieved January 22, 2018, from http://bit.ly/2hCrcEH

Al-Hindi. J. (1974). Kanz al-Ummal. Hyderabad, 35 vols. 21: 194.

Al-Jazeera. (2017). Gaza's Electricity Crisis. Retrieved December 22, 2017, from http://bit.ly/2yu9rlg

Almughrabi, N. (2017). Abbas turns screw on Hamas by cutting Gaza's electricity. Reuters, 27 April 2017. Retrieved January 22, 2018, from http://reut.rs/2pCTmoM

Alshair, D. (2017). Interview with the Research Assistant. Reasons for High Fertility Rate. Gaza, Palestine.

Alternative Information Centre. (2016). Palestinian Population will double by 2050.Alternative Information Center (AIC). Retrieved January 22, 2018, from http://bit.ly/2ziqnKM

Arafat, M. (2014). Is over-population in Gaza an act of Resistance? The New Arab, April 5, 2014. Retrieved January 22, 2018, from http://bit.ly/2xXnOu8

Boserup, E. (1985). Economic and Demographic Interrelationships in Sub-Sahara Africa. Population and Development Review, 11(3), 383-397.

Brauner-Otto, S. R., \& Axinn, W. G. (2017). Natural resource collection and desired family size: a longitudinal test of environment-population theories. Population and Environment, 38(4), 381-406. Retrieved January 22, 2018, from http://doi.org/10.1007/s11111-016-0267-6

Burton, J. W. (1987). Resolving Deep-Rooted Conflict: A Handbook. Lanham, MD and London: University Press of America.

CEPED. (1998). The French Center for Population and Development. The CEPED News: 1-5.

Choucri, N. (1986). Demographics and conflict. Bulletin of the Atomic Scientists, 42(4), 24-25. Retrieved January 22, 2018, from http://bit.ly/2zj1yyv

Coghaln, A. (2014). The reasons why Gaza's population is so young. New Scientist, 1 August 2014. Retrieved January 22, 2018, from $\mathrm{http}: / / \mathrm{bit} .1 \mathrm{y} / 2 \mathrm{~h} 2 \mathrm{zHYO}$

Courbage, Y., Abu Hamad, B., \& Zagha, A. (2016). Palestine 2030 Demographic Change: Opportunities for Development (report). UNFPA.

Daly, H. E. (2004). Population, Migration, and Globalization. World Watch Magazine. Retrieved January 22, 2018, from http://bit.ly/2zc0QD1

De Sherbinin, A. (1996). Human Security and Fertility: The Case of Haitii. Journal of Environment and Development, 5(1), 28-45.

Degomme, O., \& Guha-Sapir, D. (2010). Patterns of mortality rates in Darfur conflict. The Lancet, 375(9711), 294-300. Retrieved January 22, 2018, from http://doi.org/10.1016/s0140-6736(09)61967-x

El-Abed, O. (2009). Settling and Surviving in Egypt. Unprotected Palestinians in Egypt since 1948.US Institute for Palestine Studies and the International Development Research Centre, 58-78. Retrieved January 22, 2018, from http://bit.ly/2xWttkb

Eloundou-Enyegue, P., Stokes, C. S., \& Cornwell, G. T. (2000). Are there Crisis-Led Fertility Declines? Evidence from Central Cameroon. Population Research and Policy Review, 19, 47-72. 
Ennab, R. W. (1994). Population and Demographic Developments in the West Bank and Gaza Strip until 1990. UNCTAD. Retrieved January 22, 2018, from http://bit.ly/2yuoBas

Food and Agriculture Organisation. (2017). Gaza crisis. Retrieved January 22, 2018, from http://bit.ly/1hrrc7V

Gebremariam, W. (2008). Recent fertility decline in Eritrea: Is it a conflict led transition? Demographic Research, 18(2), 27-85.

Goldstone, J. A. (2002). Population and Security: How Demographic Change Can Lead to Violent Conflict. Journal of International Affairs, 56(1), 3-21. Retrieved January 22, 2018, from http://bit.ly/2zvTj36

Goldstone, J. A., Toft, M. D., \& Kauffman, E. (2012). Political demography: how population changes shape international security and global politics. Boulder, CO: Paradigm Publishers.

Groisman, M. (2016). Suicide Wave Hits Gaza Strip in Light of Citizens' Gloomy Day-To-Day Life. Jerusalem Post. 22 February 2016. Retrieved January 22, 2018, from http://bit.ly/1P6KnmW

Guay, J. (2015). Social cohesion between Syrian refugees and urban host communities in Lebanon and Jordan. World Vision. $\quad$ Retrieved January 22, from https:/www.wvi.org/disaster-management/publication/social-cohesion-between-syrian-refugees-and-urbanhost-communities

Hamoudeh, W. (2014). Addressing Family Planning Delivery Gaps in the Palestinian Territory. Population. Reference Bureau (PRB). Retrieved January 22, 2018, from http://bit.ly/2hbNfoG

Harab, F. (2018). Interview with the Research Assistant. Reasons for High Fertility Rate. Gaza, Palestine.

Hilal, J. (2007). Assessing the Impact of Migration on Palestinian Society in the West Bank and Gaza. European University Institute. Retrieved January 22, 2018, from http://bit.ly/2zvlgrQ

Hill, K. (2004). A Roundtable on the Demography of Forced Migration. In Anon (Ed.), War, Humanitarian Crisis, Population Displacement and Fertility: A Review of Evidence. New York: Mailman School of Public Health, Columbia University.

Huntington, S. (1993). The Clash of Civilizations?. Foreign Affairs, 72(3), 22-49.

Institute for Middle East Understanding. 2006 Palestinian Social Customs and Traditions. Retrieved December 12, 2017, from http://bit.ly/2zvlAXc

Kahl, C. (2002). Demographic Change, Natural Resources and Violence: The Current Debate. Journal of International Affairs, 56(1), 257-282. Retrieved January 22, 2018, from http://bit.ly/2A6A3W2

Kareem, A. (2014). Interview with the Author. In person: Reasons for Asylum. Gothenburg, Sweden.

Khaled. I (2013). Interview with the author. In person. Reasons for Seeking Asylum, Poland.

Khayyat, A. (1994). A Problem for Palestine: Gaza's Birthrate Highest in Middle East. Retrieved January 22, 2018, from http://bit.ly/2ivgkZ0

Khlat, M., Deeb M., \& Courbage, Y. (1997). Fertility Levels and Differentials in Beirut during Wartime: An Indirect Estimation Based on Maternity Registers. Population Studies, 51(1), 85-92.

Levine, M. (2009). Tracing Gaza's chaos to 1948. Al-Jazeera online. Retrieved January 22, 2018, from http://bit.ly/2nu2KrS

Lin, J. Y. (2012). Youth Bulge: A Demographic Dividend or a Demographic Bomb in Developing Countries. The World Bank Blog, 1 May 2012. Retrieved December 31, 2017, from http://bit.ly/1SFF2DF

Lindstrom, D. P., \& Berhanu, B. (1999). The Impact of War, Famine, and Economic Decline on Marital Fertility in Ethiopia. Demography, 36(2), 247-261.

Mahmoud, S. (2012). Interview with the author. In person: Reasons for Seeking Asylum. Athens.

Maser, S. M. (1985). Demographic actors affecting constitutional decisions: the case of municipal charters. Public Choice, 47(1), 121-162. Retrieved December 31, 2017, from http://bit.ly/2zdG71Y

MEO. (2016). PCBS reports: 'Gaza Strip Is The Most Densely Populated Place On Earth'. Middle East Observer. Retrieved December 31, 2017, from http://bit.ly/2DTNavU

Mohammed, A. (2017). Interview with the research assistant. In person. Reasons for High Fertility Rate. Gaza, Palestine. 
Murphy, D. (2017). Where is the world's densest city?. The Guardian, 11 May 2017. Retrieved January 22, 2018, from http://bit.ly/2pCGnzw

OCHA. (2017). The humanitarian impact of the internal Palestinian divide on the Gaza Strip June 2017. Retrieved January 22, 2018, from http://bit.ly/2upySP4

O'Sullivan, A. (2011). Palestinians Reveal Emigration Statistics for First Time. The Jerusalem Post, 2 January 2011. Retrieved January 22, 2018, from http://bit.ly/2zcljrK

Palestinian Central Bureau of Statistics. (2012). Palestinians at the end of 2012. Retrieved January 22, 2018, from http://bit.ly/2zcFDH2

Palestinian Central Bureau of Statistics. (2017). Palestinian youth survey, 2015 main findings. Retrieved January 22, 2018, from http://bit.ly/2E5hdnK

Pedersen, J., Randall, S., \& Khawaja, M. (2001). Growing fast: The Palestinian population in the West Bank and Gaza Strip. FAFO Institute for Applied Social Science. Retrieved January 22, 2018, from http://bit.ly/2itNFDJ

Policy and Conflict Research, Harvard University, June. (2006). Population Projections for Socioeconomic Development in the Gaza Strip. Retrieved January 22, 2018, from https://electronicintifada.net/content/information-brief-gaza-economy/6444

Rempel, T. M. (2006). Palestinian Refugees in the West Bank and the Gaza Strip. Forced Migration. Retrieved January 22, 2017, from http://bit.ly/2hah6Og

Robinson, G. E. (2008). Palestinian Tribes, Clans, and Notable Families. Strategic Insights, 7(4). Retrieved January 22, 2018, from http://bit.ly/2yshyyQ

Roy, S. (2007). Failing Peace: Gaza and the Palestinian-Israeli Conflict. London: Pluto Press.

Rutenberg, N., \& Diamond, I. (1993). Fertility in Botswana: The Recent Decline and Future Prospects. Demography, 30(2), 143-157.

Saigh, R. (1980). Encounters with Palestinian Women under Occupation. Journal of Palestine Studies, 10(4). Retrieved January 22, 2018, from http://bit.ly/2hBEvFd

Saunders, J. (1991). Introduction: Population and Security. In L. Freedman, \& J. Saunders (Eds.), Population Change and European Security. London: Brassey's.

Schembri, K. (2010). A generation trapped - Gaza's youth in figures. The Mediterranean Cultures Site, March 2010. Retrieved December 31, 2017, from http://bit.ly/2zfKNUN

Sheikh, S. (2017). Interview with the author. In person. Reasons for Seeking Asylum. London, U.K.

Smith, C. D. (2007). Palestine and the Arab-Israeli Conflict: A History with Documents. Macmillan.

$\mathrm{Su}$, A. (2015). If Gaza's borders were opened, 100,000 young people would leave. Aljazeera America, 6 May 2015. Retrieved January 22, 2017, from http://bit.ly/1Pr1zxQ

Swain, A. (1996). Environmental Migration and Conflict Dynamics: Focus on Developing Regions. Third World Quarterly, 17(5), 959-973.

Syre, W., \& Olmsted, J. (1999). Economics of Palestinian Return Migration. Middle East Report, 29(MER212). Retrieved January 22, 2017, from http://bit.ly/2zaGg43

Thabet, M., Thabet, S., \& Vostanis, P. (2016). The Relationship between War Trauma, PTSD, Depression, and Anxiety among Palestinian Children in the Gaza Strip. Health Science Journal, 10(5). Retrieved January 22, 2018, from http://bit.ly/2A6Vc2n

Thayer, B. A. (2009). Considering population and war: a critical and neglected aspect of conflict studies. Philosophical Transactions of the Royal Society, 364, 3081-3092. Retrieved January 22, 2018, from http://bit.ly/2h5OKBe

UNDP. (2016). Building Resilience in Gaza: Challenges and opportunities. Retrieved January 22, 2018, from http://bit.ly/2zaurdX

United Nations. (2016). Population Growth in Occupied Palestinian Territory to drive demand for housing, services UN, Gaza situation. Report 94 . Retrieved January 22, 2018, from http://bit.ly/2zvtsbl

UNRWA. (2015). Gaza Situation Report. Retrieved January 22, 2018, from http://bit.ly/2zvtsbl2yIk2rz 
UNRWA. (2017). Where we Work. Retrieved January 22, 2018, from http://bit.ly/2yIk2rz

UNSCO. (2017). Gaza 10 years later. UN Country Team in Occupied Palestinian Territory. Retrieved January 22, 2018, from http://bit.ly/2t7MrGk

Woldemicael, G. (2008). Recent fertility decline in Eritrea. Demographic Research, 18, 27-58.

World Bank. (2015). Gaza Economy on the Verge of Collapse, Youth Unemployment Highest in the Region at 60 percent in The World Bank. Retrieved January 22, 2018, from http://bit.ly/1FsqD5a

World Bank. (2016). Water situation alarming in Gaza. Retrieved January 22, 2018, from http://bit.ly/2ntM0kC

World Bank. (2017b). The World Bank in West bank and Gaza. Retrieved December 31, 2017, from http://bit.ly/2BJnHDC

World Book. (2017a). Palestine population. World Book Review. Retrieved January 22, 2018, from http://bit.ly/2A55VKE

\section{Notes}

Note 1. Research assistant's interview with Dr Dirdah Alshair, Palestinian Academic, 31 January 2018.

Note 2. Research assistant interview with the father.

Note 3. Research assistant interview. Mrs Fatin Harab, Women activist, 31 January 2018.

Note 4. Author interview. Anonymous Gazan migrant, Sweden. 14 August 2014.

Note 5. Author interview. A. Kareem: Gazan migrant, Sweden. 14 August 2014.

Note 6. Author interview. Gothenburg. 2014.

Note 7. Author interview, Dr Saed. London U.K. August 2017.

Note 8. Author telephone interview. January 2018.

Note 9. Author interview. Cairo. 2015.

Note 10. This was due to the migration of more enlightened and educated social groups and because a large proportion of emigrants have been influenced by the conservative culture prevailing in some of the recipient countries.

\section{Copyrights}

Copyright for this article is retained by the author(s), with first publication rights granted to the journal.

This is an open-access article distributed under the terms and conditions of the Creative Commons Attribution license (http://creativecommons.org/licenses/by/4.0/). 